\title{
Short-term velocity variations on Hansbreen, a tidewater glacier in Spitsbergen
}

\author{
Andreas VIELI,,${ }^{1,2 *}$ Jagek JANiA,${ }^{3}$ Heinz BLATTER,${ }^{1}$ Martin FUNK ${ }^{2}$ \\ ${ }^{1}$ Institute for Atmospheric and Climate Science, Eidgenössische Technische Hochschule, Winterthurerstrasse 190, CH-8057 Zürich, Switzerland \\ ${ }^{2}$ Section of Glaciology, Versuchsanstalt für Wasserbau, Hydrologie und Glaziologie, ETH-Zentrum, CH-8092 Zürich, Switzerland \\ E-mail: a.vieli@bristol.co.uk \\ ${ }^{3}$ Department of Geomorphology, Faculty of Earth Sciences, University of Silesia, ul. Będziniska 60, PL-41-200 Sosnowiec, Poland
}

\begin{abstract}
Spatial and temporal variations of the flow of Hansbreen, a tidewater glacier in southern Spitsbergen, Svalbard, are investigated. During summer 1999, surface flow velocities were measured in the ablation zone of Hansbreen with a temporal resolution of 3-4 hours. Short events with strongly increased surface velocities and a typical duration of 1-2 days were observed. These "speed-up events" are related to periods of strongly increased water input to the glacier, due to rainfall or enhanced surface melt. A close relation is found between the surface velocities and water pressure recorded in a moulin. However, there are indications from a short time lag between velocity and water-pressure peak as well as from observed vertical surface uplifts that basal motion is related to basal water storage rather than directly to basal water pressure. The observed short-term velocity variations and associated processes on Hansbreen are very similar to those observed on land-based valley glaciers and suggest that the relevant mechanisms and physical processes that control the flow and its temporal variations are similar. In contrast to the flow of land-based glaciers, sliding velocities on Hansbreen are observed to be high all year round and velocities increase towards the calving front.
\end{abstract}

\section{INTRODUCTION}

This study presents observations of short-term flow variations of Hansbreen, a small $(16 \mathrm{~km})$ and slowly flowing $\left(100 \mathrm{~m} \mathrm{a}^{-1}\right)$ tidewater glacier located in Spitsbergen, Svalbard. We use these data together with meteorological and hydrological data to obtain further insight to the causes and controlling mechanisms of the flow variations of tidewater glaciers on time-scales of hours to seasons, and discuss similarities to and differences from the comprehensively studied land-based valley glaciers. The emphasis of this paper is directed towards observed short-term speed-up events and the processes related to them.

Temporal variations in glacier flow have been observed over daily to seasonal time-scales on many glaciers. Geometry and the driving stress do not significantly change over such time-scales, so such flow variations are often assumed to be due to changes in the basal boundary condition (Willis, 1995). A number of land-based valley glaciers are known to exhibit periods of strongly enhanced surface velocities lasting for a few days (Iken and others, 1983; Harrison and others, 1986; Iken and Bindschadler, 1986; Raymond and Malone, 1986; Jansson and Hooke, 1989; Naruse and others, 1992; Willis, 1995; Truffer and others, 2001). A two- to five-fold increase in surface velocities and a duration of 1-2 days have typically been observed. Such "speed-up events" generally occur during the melt season and are often

\footnotetext{
* Present address: Bristol Glaciology Centre, School of Geographical Sciences, University of Bristol, Bristol BS8 1SS, England.
}

associated with a vertical surface uplift of the order of a few decimetres (Iken and others, 1983; Kamb and Engelhardt, 1987; Truffer and others, 2001; Gudmundsson, 2002) and variations in patterns of surface strain (Raymond and Malone, 1986; Jansson and Hooke, 1989; Mair and others, 2001). On Variegated Glacier, Alaska, U.S.A. (Kamb and Engelhardt, 1987), and Findelengletscher, Switzerland (Iken and Bindschadler, 1986), the velocity peaks were observed to propagate down-glacier at speeds of between 100$300 \mathrm{~m} \mathrm{~h}^{-1}$. In general, such speed-up events are explained by transient high basal water pressure created by enhanced water input to the basal drainage system.

On tidewater glaciers, which are defined as grounded calving glaciers ending in the sea, similar speed-up events were first detected by Voigt (1979), on Kongsvegen and Kongsbreen, Svalbard, and studied in detail on Columbia Glacier (Kamb and others, 1994; Meier and others, 1994) and LeConte Glacier (O'Neel and others, 2001), both located in Alaska. As with land-based valley glaciers, these events are related to enhanced water input due to rainfall or intense melting, and have a typical duration of a few days. In contrast to the two- to five-fold increase in velocities during speed-up events on land-based valley glaciers, the velocity increase for both of these large tidewater glaciers is $<30 \%$ of the annual value, but flow velocities are very high throughout the year $\left(5-15 \mathrm{~km} \mathrm{a}^{-1}\right)$. Although for Columbia Glacier the observations show that rapid basal motion is caused by high basal water pressure, they do not support a direct relationship between basal motion and water pressure (Kamb and others, 1994). Instead, basal water storage by cavitation at the bed has been suggested as the control 


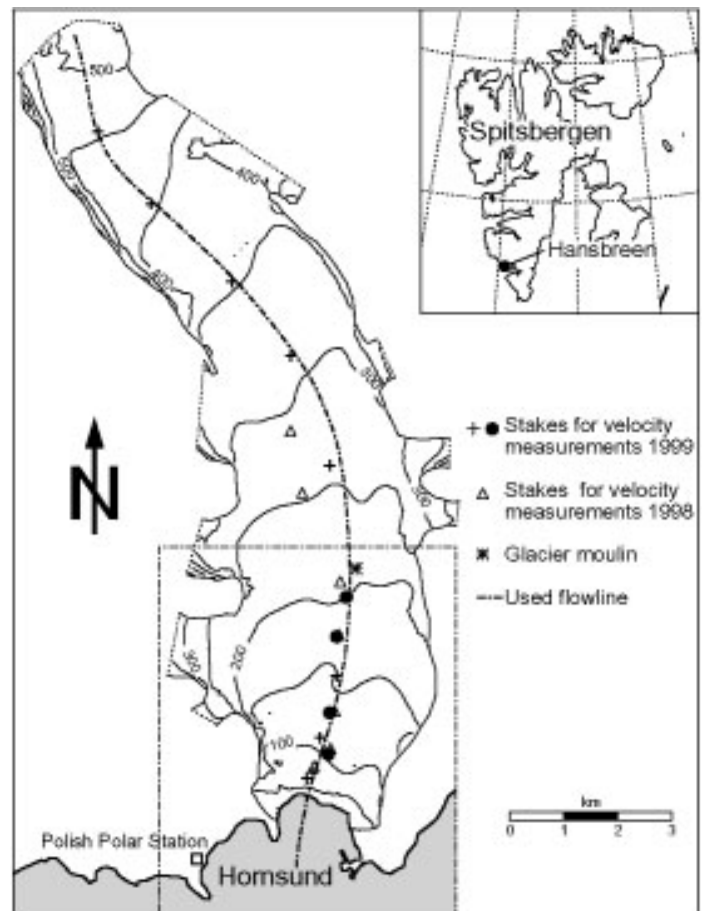

Fig. 1. Map of Hansbreen showing surface topography and the stakes used for velocity measurements. The contour interval is $50 \mathrm{~m}$. The solid black dots indicate the locations of the four continuously operating GPS stations.

variable for basal motion. For LeConte Glacier (O'Neel and others, 2001) a similar relationship between basal motion and water storage was observed.

The flow regime of tidewater glaciers is characterized by generally high basal velocities all year round (Meier and Post, 1987; Van der Veen, 1996) and increasing flow velocities towards the calving front, which are both mainly due to perennially high water pressure in the terminus region (Kamb and others, 1994; Vieli and others, 2000). Despite these differences in general flow regime between the large tidewater glaciers and land-based valley glaciers, the short-term variations, although much less dramatic, appear to have similar causes. That does not necessarily imply that the mechanisms controlling short-term flow variations are the same. The flow and hydrology of small, slowly flowing tidewater glaciers have been less extensively studied, especially on short time-scales. This paper aims to determine whether or not the characteristics and causes of short-term flow patterns of such slowly flowing tidewater glaciers are similar to those on land-based valley glaciers.

\section{Hansbreen}

Hansbreen is a tidewater glacier situated in southern Spitsbergen (Fig. 1). The glacier is about $16 \mathrm{~km}$ long and flows from a glacierized saddle at $500 \mathrm{~m}$ a.s.l. down to the sea, where it calves into Hornsund. The average surface slope is, at $1.8^{\circ}$, rather shallow, and almost all surface-derived meltwater flows into moulins. The lower $12 \mathrm{~km}$ of the glacier bed is below sea level and has a maximum depth of $100 \mathrm{~m}$ below sea level and a maximum ice thickness of about $350 \mathrm{~m}$.

The flow regime of the frontal region of Hansbreen was first investigated by Pillewizer (1939) and later by Jania and Kolondra (1982) using terrestrial photogrammetry. They found that average velocities increased towards the glacier

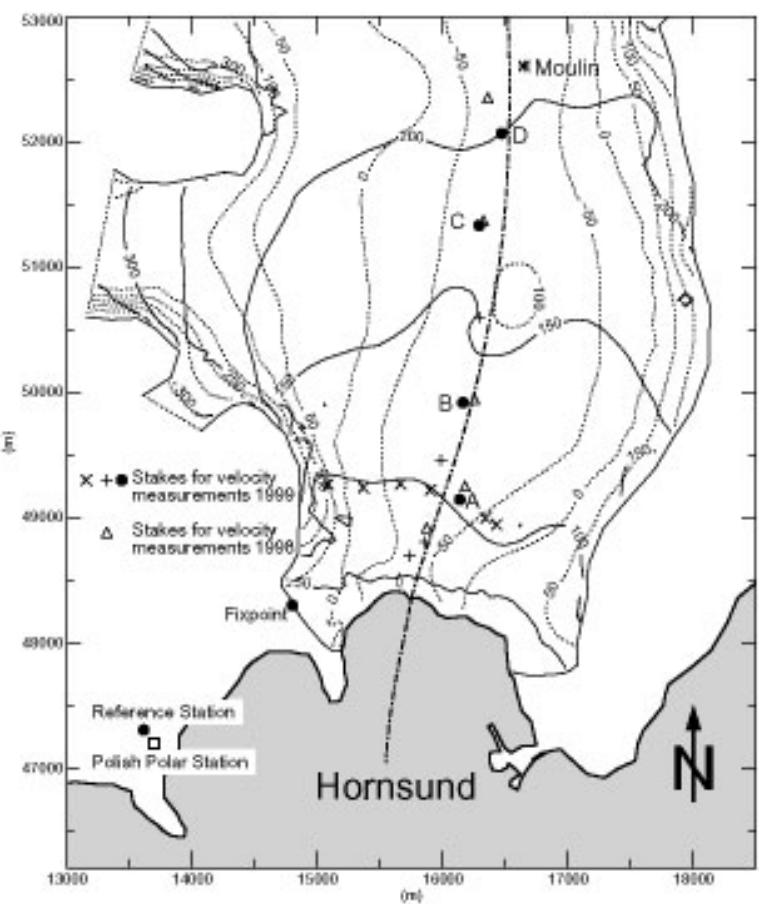

Fig. 2. Map of the frontal region of Hansbreen showing the location of the stakes used for velocity measurements. The continuously operating GPS stations are indicated by solid black dots. The cross symbols mark the positions of the additional poles for the transverse $(\times)$ and longitudinal $(+)$ velocity profile. The solid and dashed contours show the glacier surface and bed topography respectively. The contour intervals are $50 \mathrm{~m}$.

terminus. Temporal variations in surface flow have been observed over a range of intra-annual time-scales (Jania, 1988); however, the measurement intervals were generally longer than 5 days. In summer 1998, surface velocity measurements were performed by terrestrial survey with a temporal resolution of 1 day (Vieli and others, 2000; Fig. 1). Substantially enhanced surface velocities were observed during short periods of significantly increased melt rates related to föhn. The duration of these speed-up events was 1-3 days. In the lower $4 \mathrm{~km}$ of the glacier, a significant increase in flow velocities towards the terminus was observed. Vieli and others (2000) showed that decreasing effective subglacial pressure towards the calving front was mainly responsible for the increase in basal sliding. Using a numerical glacier flow model that includes an effective pressuredependent sliding law, a good agreement between measured

Table 1. Horizontal and vertical a posteriori error of the GPS measurements at the different stations

\begin{tabular}{ccccc}
\hline $\begin{array}{c}\text { Station } \\
\text { name }\end{array}$ & $\begin{array}{c}\text { Baseline } \\
\text { length }\end{array}$ & $\begin{array}{c}\text { Difference in elevation } \\
\text { to reference station }\end{array}$ & $\sigma_{\text {hor }}$ & $\sigma_{\text {ver }}$ \\
& $\mathrm{km}$ & $\mathrm{m}$ & $\mathrm{mm}$ & $\mathrm{mm}$ \\
\hline Fixpoint & 1.8 & 26 & 4 & 13 \\
A & 3.0 & 69 & 5 & 17 \\
B & 3.5 & 113 & 5 & 17 \\
C & 4.8 & 148 & 7 & 23 \\
D & 5.5 & 183 & 9 & 29 \\
\hline
\end{tabular}



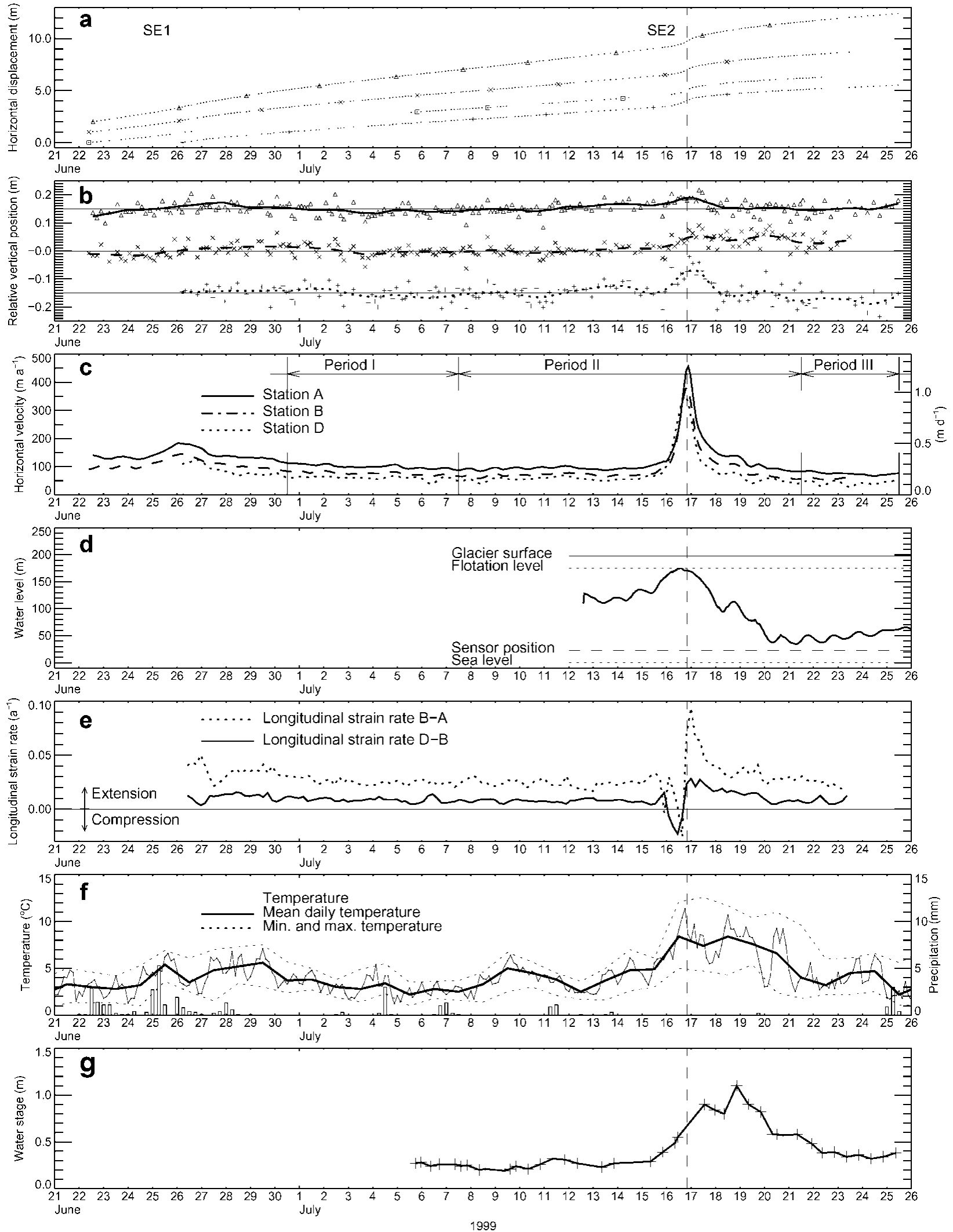

Fig. 3. Time series during the period of investigation in summer 1999. (a) Single measurements (dots) of the relative horizontal position of the four stations $A(\triangle), B(\times), C(\square)$ and $D(+)$. SE1 and SE2 and the vertical dashed lines refer to the first and second speed-up events. ( $b$ ) Relative vertical position (subtracted from general trend) of stations $A, B$ and $D$ for single measurements (symbols) and the smoothed data (lines: A solid, B dashed and D dotted). (c) Horizontal velocities for stations A, $B$ and D. For periods I-III see Table 3 and Figure 6b. (d) Water pressure measured in a moulin shown as water level above sea level. (e) Longitudinal strain rates between stations $B$ and $A$ (dotted line) and D and B (solid line); a positive value indicates extension. (f) Air temperature (lines) and precipitation (vertical bars) measured at the meteorological station near Hansbreen. (g) Water level of the outflow river of neighbouring Werenskioldbreen. 
and modelled velocity was obtained, in particular for the frontal acceleration pattern.

In this paper, we present the results of fieldwork carried out in summer 1999. A much higher temporal resolution (a few hours) than in the previous studies has been used, allowing the detailed characteristics of short-term events to be determined and their controlling processes investigated. In the 1999 campaign, meteorological and hydrological data were also collected and the area in which velocities were measured was extended from the lower ablation area over the whole length of Hansbreen.

\section{METHODOLOGY}

Four global positioning system (GPS) stations were set up along the central flowline of Hansbreen (labelled A-D; Fig. 2). The lowest station was located $800 \mathrm{~m}$ behind the calving front, and the highest one $3.6 \mathrm{~km}$ away from the front. The GPS stations were mounted on aluminium poles drilled $5 \mathrm{~m}$ into the ice. A fifth GPS receiver was installed off the glacier, close to the Polish polar station, and was used as a reference station. Three (A, B and D) of the four stations were in continuous operation from 21 June to 26 July 1999. Positional measurements were determined at intervals of 3-4 hours, depending on satellite availability. The mission duration was about $20 \mathrm{~min}$. Both the L1 and L2 phase signals were recorded. Data processing was performed with the Leica SKI software (Version 2.2).

The a priori error of a GPS measurement is specified as $\pm 3 \mathrm{~mm} \pm 2 \mathrm{ppm}$ in the horizontal, and about twice as much in the vertical direction. For two short periods of 5 and 7 days duration, station $\mathrm{G}$ was moved to a fixed point off the glacier (labelled Fixpoint in Fig. 2). The data from this fixed point are additionally used to determine the a posteriori error shown in Table 1 (Vieser, 2000). For the horizontal position, the a posteriori error $\sigma_{\text {hot }}$ is specified with $\pm 3 \mathrm{~mm} \pm 1 \mathrm{ppm}$ and is slightly better than the a priori value. The vertical a posteriori error $\sigma_{\text {ver }}$ is specified with 3.2 times the horizontal value, which is significantly worse than the a priori value. This is due to the fact that no satellites pass near the zenith at such high latitudes $\left(77^{\circ} \mathrm{N}\right)$.

Horizontal velocities were derived from a smooth cubicspline interpolation of the measured horizontal stake positions using the LOKERN Fortran routine (Kernel regression smoothing with local plug-in bandwidth; Seifert and others, 1994). The a posteriori errors (Table 1) were used as input for the smoothing routine. For the smoothed horizontal velocity data, we estimate an error of about $4 \mathrm{~cm} \mathrm{~d}^{-1}$, corresponding to a maximum relative error of about $20 \%$ during slow-flow periods. However, the relative error during the observed speed-up events is much lower. The same smoothing method has been used for the vertical displacement.

In addition to stations $\mathrm{A}-\mathrm{D}$, nine poles were set up along the flowline between the calving front and the top of the glacier, spaced 500-2000 $\mathrm{m}$ apart (Fig. 1), and six additional poles were positioned in a transverse profile, $800 \mathrm{~m}$ up-glacier from the calving front, spaced $250 \mathrm{~m}$ apart (Fig. 2). Along both profiles, GPS measurements were repeated up to four times during the investigation period, at intervals of a few days to weeks.

Water pressure was measured with a vibrating wire pressure sensor (Geokon) in an active moulin, situated $500 \mathrm{~m}$
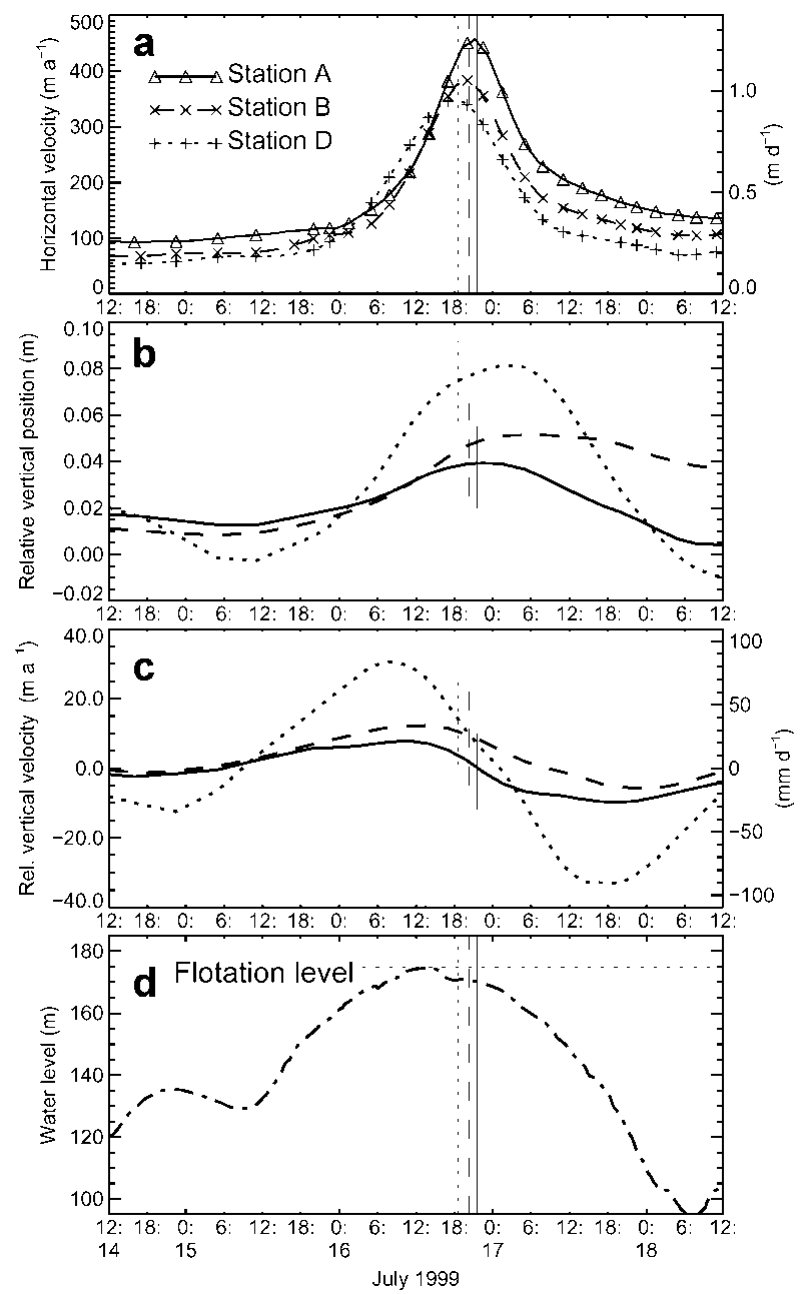

Fig. 4. Close-up view of SE2. (a) Horizontal surface velocities of stations $A, B$ and $D$. The symbols stand for individual position measurements. (b) Smoothed vertical displacement (after subtracting linear trend), and (c) corresponding smoothed vertical velocity. (d) Water level in the moulin. The time of maximum water level is indicated by the vertical dashed dotted line, and the other vertical lines indicate the peak time of the horizontal velocities at the three different stations.

up-glacier from the highest GPS receiver D (Fig. 2). Pressure measurements were carried out every $30 \mathrm{~s}$, and the averaged values over 15 min were stored. The pressure data were converted to metres of water above sea level. The absolute depth of the sensor was estimated as $173 \pm 7 \mathrm{~m}$ below the glacier surface, corresponding to $25 \pm 7 \mathrm{~m}$ a.s.l. The glacier bed at this location is $81 \mathrm{~m}$ below sea level. The sensor was installed on 12 July, 1 day after the moulin became accessible through the winter snowpack.

Meteorological data were recorded at a meteorological station, maintained by the Institute of Geophysics of the Polish Academy of Science, situated at the Polish polar station, 15 m.a.s.l. about $2 \mathrm{~km}$ from the glacier terminus (Fig. 2). Ablation was measured several times during the investigation period at the same poles used for the GPS measurements. Runoff from the neighbouring land-based Werenskioldbreen was estimated by measuring the water level in the river draining the glacier at half-day intervals and was used as a proxy for temporal changes in the meltwater discharge from Hansbreen. 


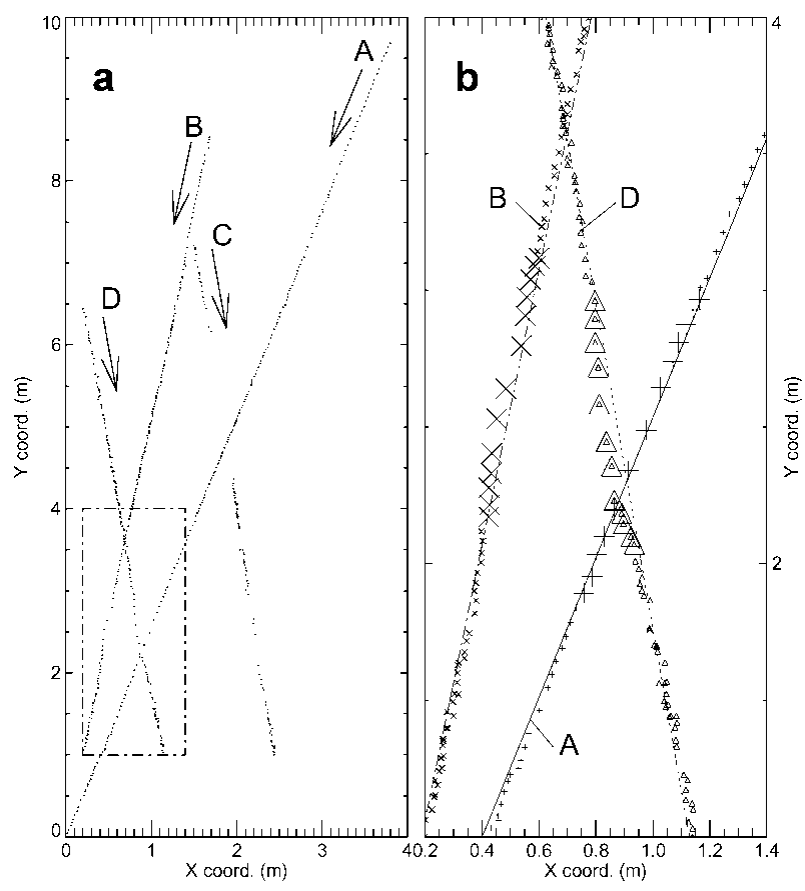

Fig. 5. (a) Plane view of all measured relative positions of GPS stations $A-D$ (shown in arbitrary coordinates). The arrows indicate the general flow directions. (b) Close-up of the indicated section in (a). Large symbols indicate position measurements between $0000 \mathrm{~h}$ on 16 Fuly and $1600 \mathrm{~h}$ on 17 Fuly, corresponding to the period of SE2.

\section{RESULTS}

\section{Velocity and vertical displacement}

\section{Temporal velocity variations}

The measured horizontal displacement and the horizontal velocities of stations A, B and D are shown in Figure 3a and c. For station $\mathrm{C}$, only horizontal displacement is shown, because of gaps in the data. The velocity and displacement records show two distinct speed-up events, both lasting about 2 days, which were detected at all four stations (Fig. $3 \mathrm{a}-\mathrm{c}$ ). During speed-up event 1 (labelled SEl) the velocities increased by a factor of 1.5 from about $0.26 \mathrm{~m} \mathrm{~d}^{-1}$ to $0.4 \mathrm{~m} \mathrm{~d}^{-1}$, and reached a maximum on 26 June. After SE1 the velocities decreased slowly and almost steadily over a period of 8 days (until 6 July) by about $30 \%$. From 6 July until the second speed-up event (labelled SE2) the velocities are more or less stable at these values. SE2 started on 15 July and was much more pronounced than SEl; the velocities increased by a factor of 5 and reached maximum values of $1.25 \mathrm{~m} \mathrm{~d}^{-1}$ during the evening of 16 July. The velocity peaks during SE2 at the different stations are slightly shifted in time (Fig. 4a). Maximum velocity was first reached at the uppermost station, D, and occurred later at stations B and $\mathrm{A}$. The lag in peak velocity between stations D and A is about 3 hours (which is close to the temporal resolution of the observations) and is equivalent to an average propagation velocity for the peak of about $1 \mathrm{~km} \mathrm{~h}^{-1}$. After SE2, the velocities decreased within a few days to levels about $25 \%$ lower than before the event.

Diurnal velocity fluctuations are visible in Figure 3c, but they are within the error bar of the GPS measurements and may be systematic errors associated with the differential GPS method (Vieser, 2000). Similar diurnal variations
Table 2. Amount of ice melted ( $m m d^{-1}$ ) for three different time periods. The error in the ablation measurements is $\pm 10 \mathrm{~mm} \mathrm{~d}^{-1}$

\begin{tabular}{|c|c|c|c|}
\hline \multirow[b]{2}{*}{ Station name } & \multicolumn{3}{|c|}{ Ablation of ice } \\
\hline & $\begin{array}{c}\text { Before föhn period } \\
21.6-15.7\end{array}$ & $\begin{array}{c}\text { During föhn period } \\
15.7-18.7\end{array}$ & $\begin{array}{c}\text { After föhn period } \\
21.7-23.7\end{array}$ \\
\hline A & 27 & 98 & 43 \\
\hline B & 35 & 67 & 30 \\
\hline $\mathrm{C}$ & 23 & 72 & - \\
\hline $\mathrm{D}$ & - & 93 & 35 \\
\hline
\end{tabular}

observed on Unteraargletscher, Switzerland, using the same GPS method, were found to be artefacts caused by tropospheric delays (Meinck, 1998; Gudmundsson, 2002).

\section{Vertical displacement and change in direction of flow}

The relative change of vertical position with time of stations A, B and D is shown in Figure 3b. The symbols represent single measurements for the vertical position minus a mean vertical displacement trend over the observation period, and the lines show the same data after smoothing. The fluctuations in single measurements of the vertical position have an amplitude of about $3 \mathrm{~cm}$ and are within the a posteriori error (Table 1). For SE1 no significant change in vertical displacement was observed. For SE2 at station D, a significant uplift of about $10 \mathrm{~cm}$ was observed between 16 and 18 July, almost simultaneous with the horizontal speed-up (Fig. 3b and $4 \mathrm{c}$ ). For stations A and B, similar uplifts are indicated, but the signals are weak.

In addition to the uplift, a slight change in the direction of flow was observed for stations D and B during SE2 (Fig. 5). Both stations moved about $6 \mathrm{~cm}$ to the right of the general direction of flow during the speed-up event and switched back after it. Such a change in flow direction is not detectable for stations A and C. During SE1 none of the stations showed a significant change in flow direction.

\section{Glimatic conditions and ablation}

Surface melting started before the beginning of the measurement period. At that time the glacier was still covered with snow, which was wet in the lower regions of the glacier. After 12 July, the glacier surface in the lower $4 \mathrm{~km}$ from the terminus (including stations $\mathrm{A}-\mathrm{D}$ ) became snow-free. The temperature measured at the meteorological station was above freezing point during the entire investigation period (Fig. 3f). Around SE1, from 22 to 29 June, several rainfall events occurred. At that time, in the accumulation area, precipitation fell as snow. A 4 day föhn period started on 15 July just before SE2 and was characterized by strong easterly winds, clear sky and a $5^{\circ} \mathrm{C}$ increase in mean daily air temperature (Fig. 3f). On the glacier, the temperature increase due to the föhn was probably even higher than at the meteorological station, because the glacier is located on the lee side of a mountain ridge $800 \mathrm{~m}$ high, whereas the meteorological station is more exposed to the fjord climate. The föhn period was briefly interrupted overnight from 17 to 18 July.

Temperature is a good index for surface melting (Ohmura, 2001) and therefore suggests enhanced surface melting during the föhn period. This is supported by the 


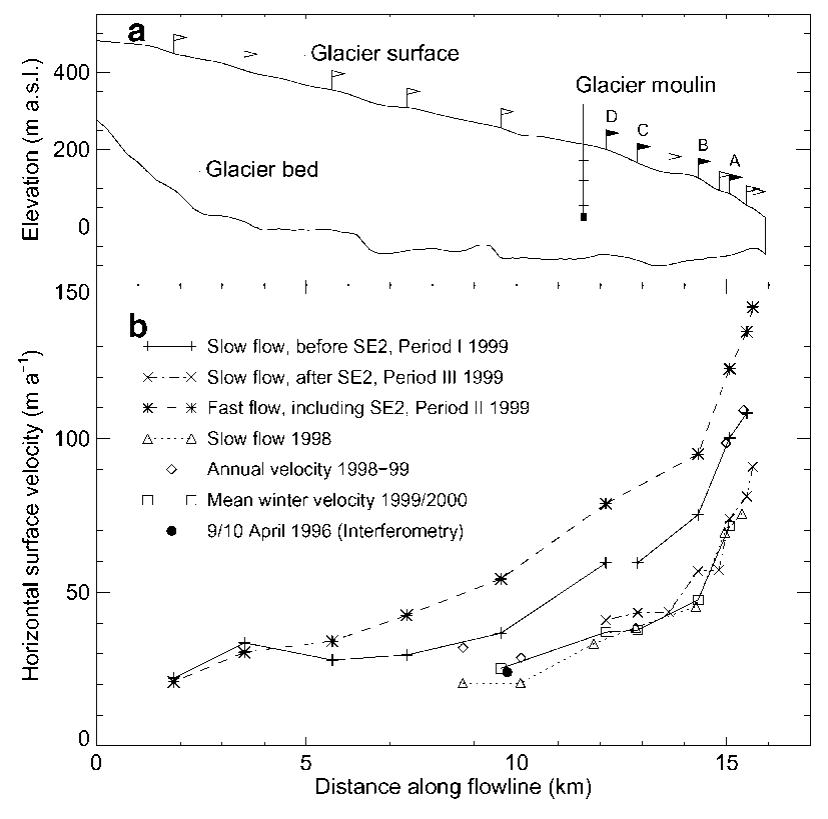

Fig. 6. (a) Glacier geometry shown along a flowline of the glacier. The locations of the four continuously operating GPS stations are indicated by the black flags; the white flags indicate the poles along the longitudinal velocity profile. In addition, the approximate location of the pressure sensor in the moulin is shown, together with the mean water level before SE2 (middle), the maximum water level (top) and the minimum level after SE2 (bottom). (b) Horizontal velocities along the flowline for different time periods.

measured increase in surface ablation by a factor of 2-3 during this period (Table 2). During the föhn period, meltwater streams formed at the surface, and the colour of the glacier surface in the terminus region changed from white to blue within a few hours. These findings further support significantly enhanced surface meltwater during the föhn event. An outburst event observed at the same time on Finsterwalderbreen, located about $70 \mathrm{~km}$ north of Hansbreen, was also triggered by enhanced surface meltwater supply (Wadham and others, 2001) and indicates that the cause of the melt event was not local.

In the ablation area of Hansbreen, almost all surfacederived meltwater flows into moulins and crevasses and is drained englacially or subglacially. Therefore the input into the glacier drainage system was enhanced during the föhn period as well as during the rainfall events. During the föhn event the glacier discharge of neighbouring Werenskioldbreen was significantly enhanced (four-fold increase in stage level) and reached a maximum on 19 July, about 2 days after the velocities on Hansbreen peaked. These runoff data can be used as a proxy for the variation in glacial discharge at Hansbreen and therefore support the idea that water discharge through the drainage system remained high during the whole 4 day föhn period.

\section{Water pressure}

The water level measured in the moulin shows strong temporal variation (Fig. 3d). Initially, on 12 July, the water level was $80 \mathrm{~m}$ below the surface. At the beginning of the föhn period on 15 July, it started to increase and reached a maximum value of $29 \mathrm{~m}$ below the surface, corresponding to the flotation level at this location. The water level peaked
Table 3. Time periods for velocity measurements along the flowline and along the transverse profile ( see Fig. 3)

$\begin{array}{lll}\text { Period I } & \text { 30 June-7 July 1999 } & \text { Slow flow before SE2 } \\ \text { Period II } & \text { 7-21 July 1999 } & \text { Including SE2 } \\ \begin{array}{l}\text { Period III } \\ 1998\end{array} & \text { 21-25 July 1999 } & \text { Slow flow after SE2 } \\ & \text { August 1998 } & \begin{array}{c}\text { Slow flow after a speed-up } \\ \text { event in 1998 }\end{array} \\ \text { 1999/2000 } & \text { 21 July 1999-2 April 2000 } & \text { Mean autumn/winter flow }\end{array}$

almost simultaneously with the horizontal velocities and then dropped by about $120 \mathrm{~m}$, to $155 \mathrm{~m}$ below the surface, which is significantly below the level observed before SE2. Daily fluctuations with an amplitude of roughly $5 \mathrm{~m}$ were superimposed on this pattern. The exception is during the first part of the föhn event, when the water level was continuously high or rising and no overnight decrease occurred.

\section{Spatial velocity variations}

The variation of surface velocities along the flowline is shown in Figure 6 for three time periods in 1999 together with earlier data from 1998 (Vieli and others, 2000). The three periods in 1999 are specified in Table 3 and indicated in Figure 3c and are confined by the times when the stakes along the flowline were remeasured. A strong increase in the surface velocity towards the terminus is observed. This acceleration pattern is similar for all time periods and seems to be independent of the temporal changes in velocity. Annual velocities derived from remeasuring the remaining stakes from the 1998 field campaign in summer 1999 (diamonds in Fig. 6b) are similar to the values from period I (SE1-SE2). The lowest velocities occurred for the two periods after strong speed-up events in 1999 and 1998. Similar mean velocities (squares in Fig. 6b) were obtained for the period 21 July 1999 to 2 April 2000 (winter 1999/2000) from remeasuring five stakes used in 1999 by GPS in the following spring. In Figure 6, an additional velocity value from 9/10 April 1996 is shown, which was derived from interferometric analysis (personal communication from H. Rott, 1998). The new data from 1999 also show that in the upper $5 \mathrm{~km}$ of the glacier the velocities did not significantly change with time.

Surface velocities in a transverse profile, located $800 \mathrm{~m}$ behind the terminus (Fig. 2), are shown for different time periods in Figure 7. Crevasses prevented measurements from being made towards the eastern margin. Maximum velocities are shifted $200 \mathrm{~m}$ to the east of the zone of greatest ice thickness, and the velocities decrease to zero towards the western margin. The transverse velocity pattern does not change significantly between a period of slow flow and one including a speed-up event.

\section{INTERPRETATION AND DISGUSSION}

\section{Short-term variation}

The very short time-scales involved in the observed speedup events suggest that the drastic changes in surface flow are mainly caused by changes in basal motion and not by internal ice deformation. The ablation and meteorological records show that both speed-up events are clearly related to periods of enhanced water input to the glacier drainage system. This suggests that the enhanced basal motion is a 


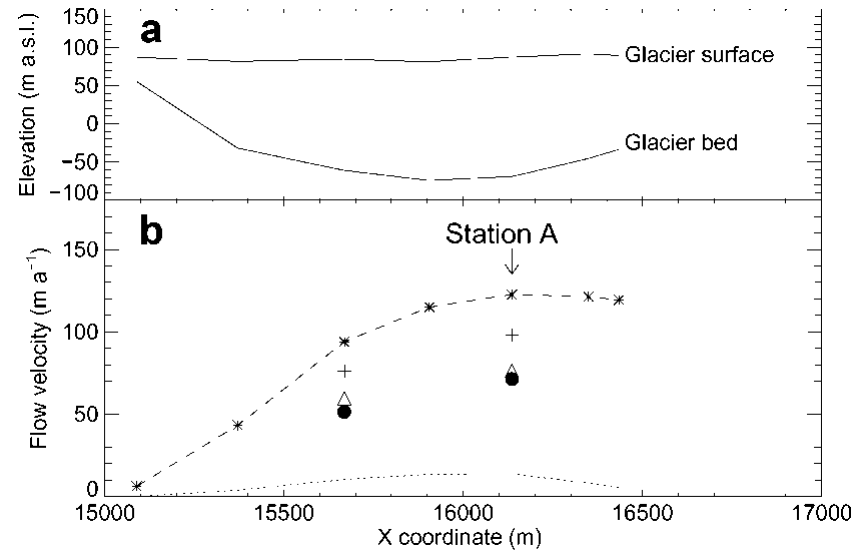

Fig. 7. Profile across Hansbreen at station A showing (a) geometry and (b) horizontal velocities for different time periods. The stars and the dashed line indicate the velocities for period II, the crosses for the period 7-8 Fuly, the triangles for the period 21-23 Fuly and the dots for the period 23-25 July. The dotted line represents the velocities due to ice deformation estimated by the shallow-ice approximation.

result of changing basal conditions (basal water pressure, water storage, the spatial distribution of water) in response to enhanced water input.

\section{Basal drainage system and speed-up}

SEl followed a rather small rain event $(10 \mathrm{~mm}$ within 18 hours $)$ and a slight increase in surface temperature $\left(2^{\circ} \mathrm{C}\right.$ within 18 hours), but because the melting season had just started, the drainage system may still have been inefficient as a result of little or no water input in winter, making the additional input sufficient to reduce basal drag and lead to the observed speed-up.

SE2 is clearly related to a föhn event, as similarly observed in 1998 (Vieli and others, 2000). From the constant, low water input into the glacier within the 10 day period before SE2 (Fig. 3f), we infer a rather inefficient basal drainage system prior to SE2. This finding is supported by the high water level observed in the moulin before SE2 (Fig. $3 \mathrm{~d}$ ). The sudden increase in water input at the beginning of the fön period therefore resulted in the increased water level observed in the moulin. Although the water input remained high throughout the 4 day period of the föhn, the water level peaked within the first day and then dropped to a much lower level than before SE2, clearly indicating a major reorganization to a more efficient, and most probably channelized, basal drainage system (Kamb and Engelhardt, 1987). These findings suggest that the enhanced basal motion during SE2 was most probably a result of a changing spatial pattern of basal shear stress induced by the subglacial hydrology, as suggested by earlier studies on valley glaciers (Hooke and others, 1989; Iken and Truffer, 1997; Fischer and others, 1999; Mair and others, 2001). The absence of diurnal variations around the water-level peak further supports a major change in the drainage system at that time.

As suggested in several studies (Humphrey and others, 1986; Raymond and others, 1995), a water input to the subglacial drainage system of Hansbreen too large to be discharged without a major readjustment of the drainage system seems to be the trigger for the speed-up events. The slightly lower velocities after SE2 than prior to it are presumed to be a result of the switch to a more efficient hydraulic system. Such a slow-down after a speed-up event was similarly observed on Unteraargletscher (Gudmundsson and others, 2000) and Columbia Glacier (Meier and others, 1994), and indicates a lasting effect of such events on the structure of the basal drainage system. The subsequent slow increase in water pressure after the drop in water level indicates a renewed adjustment of the drainage system to reduced water input, most probably by channel closure due to viscous deformation, when ice-overburden pressure exceeds water pressure (Röthlisberger, 1972). We propose that the observed duration of the motion events, $1-2$ days, which is also reflected in the pressure data, represents the time-scale required by the subglacial drainage system to adjust to a significant perturbation in water input. The similar speed-up events detected on Hansbreen in summer 1998 (Vieli and others, 2000) confirm this typical time-scale. Because speed-up events were not recorded in the upper accumulation zone (Fig. 6), a significant change in the hydraulic system probably took place only in the lower $10 \mathrm{~km}$. In the upper $5 \mathrm{~km}$, ablation was reduced and the glacier was covered by firn, and meltwater was therefore stored in the firn for some time. Thus, the enhanced water input to the basal drainage system was strongly delayed and damped, and did not lead to a major reorganization of the basal drainage system.

\section{Controls on basal motion}

The speed-up events are clearly a result of changing conditions at the bed induced by the subglacial hydrology, as described above. However, the detailed mechanism that controls basal motion is not obvious and is discussed below.

For SE2, there is a close relation between the observed velocities and water pressure within the moulin over the period of available water-level data (Fig. 3c and d). This indicates that basal motion is related to basal water pressure, as is also observed for many land-based glaciers (Iken and Bindschadler, 1986; Boulton and Hindmarsh, 1987; Hooke and others, 1989; Iverson and others, 1995; Jansson, 1995; Iken and Truffer, 1997) and suggested by theoretical studies (Lliboutry, 1968, 1979; Fowler, 1987). A "conventional” and widely used water-pressure-dependent sliding parameterization (Bindschadler, 1983) should then explain the observed enhanced basal motion. A closer look shows that the velocity peak at station $\mathrm{D}$, closest to the moulin, lags the pressure peak by 3.5 hours (Fig. $4 \mathrm{a}$ and d). This lag cannot be explained by the travel time of the velocity peak between the moulin and station $\mathrm{D}$, which would be 0.5 hours. The problem with the pressure data is that water levels are measured in a moulin and not directly at the bed below station D. Although it seems reasonable to assume that the measured water levels are somehow representative of basal water pressure, it is not obvious how the moulin is connected to the basal drainage system. Thus, it is not clear whether a time lag exists between basal water pressure and water level within the moulin and to which location the inferred basal water pressure corresponds.

The inefficient basal drainage system prior to SE2 suggests that no "perfect" interconnection existed between basal cavities at that time. The measured water pressure in the moulin is therefore presumed to represent localized basal water pressure rather than an average over a larger area of the bed, as would be expected for a direct relationship between basal motion and basal water pressure (Kamb and others, 1994; Iken and Truffer, 1997). The time lag 
between basal water pressure and water level may reflect the time needed for the pressure perturbation to spread out at the base sufficiently to be detected as a speed-up at the surface. This indicates that, although the short-term variations in basal motion are somehow related to basal water pressure, basal motion is controlled by basal water storage rather than basal water pressure directly, as also suggested for the two large tidewater glaciers Columbia (Kamb and others, 1994) and LeConte (O’Neel and others, 2001).

Another possibility would be that the moulin is not well linked to the basal drainage system and tends to fill up with water during extreme melt events. This ponded water would then force conduits to open and after a while the moulin would flush out. In this case, the moulin water level would represent basal and englacial water storage rather than basal water pressure. The observed speed-up would then be a result of the release of this stored water to the subglacial drainage system, and basal motion would be related to water storage and release rather than directly to basal water pressure. However, prior to SE2, significant discharge of water through the moulin was observed, and the repeating decrease in water level on a diurnal cycle indicates that before SE2 the moulin was to some extent already connected to the hydraulic system, which makes this alternative scenario less likely. Furthermore, the observation of two similar speed-up events a year before (Vieli and others, 2000 ) occurring within 1 week of each other, indicates that speed-up events on Hansbreen do not require a previously unconnected moulin.

O'Neel and others (2001) used the phase shift between changes in horizontal and vertical velocity to distinguish between basal water pressure and water storage as the controlling variable for basal motion. If basal water pressure controls basal motion, the maximum horizontal speed should occur simultaneously with the maximum vertical speed (Fahnestock, 1991; Paterson, 1994). However, if peaks in horizontal speed and vertical displacement are in phase, basal motion would be directly related to water storage (Iken and others, 1983). Although the relative error in our vertical displacement data is high and the signal rather noisy, at least for station $\mathrm{D}$ the horizontal velocity seems to peak when the vertical uplift is greatest (Fig. 3 b and c). Our observation that the uplift is a measure of basal water storage is justified in the next paragraph. A close-up view of SE2 showing the smoothed vertical displacement data (Fig. 4) and the inferred vertical velocities confirms this finding and indicates that it is also the case for station A. In addition, for station $\mathrm{D}$ the maximum vertical velocity is almost in phase with the peak in water level, which is consistent with the idea that the growth of basal cavities (uplift velocity) is highest when water pressure is highest (Iken and others, 1983). These observations would favour basal water storage, and not basal water pressure, as a direct control on basal motion. For station B, however, the phase relationship argument is less clear, and for all stations the signal in vertical uplift is rather small, so no conclusive answer is possible on the direct control of basal motion. In fact, basal water pressure and water storage are closely related, so the effects of the two are difficult to separate, especially over timescales longer than a few hours or days.

\section{Surface uplift}

The observed longitudinal compression at the beginning of SE2 leads to vertical extension, assuming a confined valley.
Using the observed longitudinal strain rates (Fig. 3e) and assuming constant horizontal strain rates from the surface to the base, uplift due to vertical extension is estimated to be one to two orders of magnitude smaller than the observed $10 \mathrm{~cm}$ at station $\mathrm{D}$. The high water pressure may also lead to extension of the basal sediment and result in vertical uplift, as suggested for Black Rapids Glacier, Alaska (Truffer and others, 2001). However, this explanation requires the existence of a basal sediment layer of sufficient thickness, which is not postulated for Hansbreen. Thus the most likely explanation for the uplift is basal water storage through the growth of basal cavities or bed separation as a consequence of the high basal water pressure, attaining the flotation level ("hydraulic-jack" mechanism: Iken and others, 1983; Willis, 1995). The absence of significant uplift during SEl indicates that no large amount of water was stored at the base during this speed-up event. However, this does not exclude water storage as a possible mechanism for the increase in basal motion.

\section{Temporal shift and change in flow direction}

The observed shift in the location of the velocity peak during SE2 suggests that the change in basal conditions did not occur simultaneously at the different stations and was propagating down-glacier at a speed of $1 \mathrm{~km} \mathrm{~h}^{-1}$.

Enhanced surface input occurred simultaneously over the whole ablation zone, but the drainage system was probably less efficient up-glacier than in the terminus region, so basal conditions changed earlier and faster in the upper ablation area.

The observed propagation speed of $1 \mathrm{~km} \mathrm{~h}^{-1}$ is significantly higher than the values found in land-based valley glaciers. According to Iken and Bindschadler (1986), a high value, as found for Hansbreen, would indicate low water storage outside the basal conduits, which would agree with the rather small, or absent, vertical uplifts but also contradict the suggestion that water storage is a direct control on basal motion. The high propagation speed of the velocity wave implies that the velocity peak covered a large area; that means that all stations moved with almost maximum speed over a period of several hours. This, together with a water pressure around flotation, indicates that ice-bed decoupling of larger areas occurred and led to the opening of new, efficient drainage conduits, and therefore may alternatively explain the high propagation velocity.

The downward propagation of the velocity peak results in a phase of longitudinal compression as velocities increase, and is followed by a phase of longitudinal extension as velocities decrease. The peak in longitudinal extension may lead to additional fracture and crevasse formation in the terminus region, and may therefore affect the process of calving.

The observed change in flow direction at two of the four stations (Fig. 5) is due to variations in transverse velocities, and most probably a result of the expected changing spatial pattern of basal shear stress during the reorganization of the subglacial drainage system. The switch back to the initial flow direction after SE2 may indicate a spatial pattern of basal shear stress similar to that prior to SE2.

\section{General flow characteristics}

The flow during the melt season is characterized by a rather steady flow interrupted by a few distinct, short speed-up events occurring in the ablation area. The 1999 data show 
that the occurrence of such speed-up events is not limited to the beginning of the melt season, as already indicated by measurements in 1998. This indicates that the basal drainage system is highly dynamic throughout the melt season.

There is clear evidence that, even during the slow flow periods in between speed-up events, surface flow is dominated by basal motion in the ablation area. For the transverse profile this can be seen from a rough estimate of ice deformation by the shallow-ice approximation, using the local ice thickness, surface slope and a rate factor of $6.8 \times 10^{-15} \mathrm{~s}^{-1} \mathrm{kPa}^{-3}$ for temperate ice (Paterson, 1994) and the power-law exponent $n=3$ (Fig. 7). Earlier numerical modelling by Vieli and others $(2000,2002)$ suggests that the dominance of basal motion results from the fact that the bed is well below sea level in this region and effective pressure at the bed is generally reduced. The rather low velocities in the upper accumulation area suggest that basal motion is absent or very low. There are two main reasons for this. First, the bed in the upper accumulation area is clearly above sea level, and, second, the meltwater does not directly reach the bed and is stored within the firn for some time. This is supported by the fact that the flow does not vary significantly with time in the upper accumulation area (Fig. 6).

The similar magnitudes of surface velocities during slow-flow periods in 1999 and 1998, the annual values measured between 1998 and 1999, the mean autumn/winter 1999/ 2000 values and the spring value from interferometry in 1996 (Fig. 6) suggest that the mean winter velocities are also similar, and implies that basal motion in the ablation area of Hansbreen is high all year round.

The spatial pattern of accelerating flow towards the glacier terminus, observed on Hansbreen (Fig. 6), is typical for tidewater glaciers and is distinctly different from the flow pattern of land-based valley glaciers. Vieli and others (2000, 2002) explained this spatial pattern by the fact that the effective pressure at the bed is significantly reduced towards the terminus because the bed is below sea level. They used a simple pressure-dependent sliding relation, which contradicts the suggestion that there is a direct control on basal motion by water storage. As mentioned above, on time-scales of several days and longer, it seems difficult to separate the effects of water pressure and water storage on basal motion, because they are closely related. This may explain why modelling with a water-pressure-dependent sliding relation was successful. For Columbia Glacier, rapid basal motion is also ascribed to high basal water pressure. Although near flotation, basal motion was found to be related to water storage rather than directly to basal water pressure (Kamb and others, 1994). The increase in velocity towards the terminus increases longitudinal extension (Fig. 3e), which explains the observed enhanced surface crevassing towards the terminus.

\section{GONGLUSIONS}

High-temporal-resolution surface velocity measurements carried out on Hansbreen during the 1999 melt season show that sporadic, pronounced, short-term speed-up events with a typical duration of 1-2 days occur in the ablation area. Such events are related to periods of enhanced water input to the glacier, due either to rainfall or to intensive melt events (föhn) and are not limited to the start of the melt season. The rapid changes in velocity suggest that such events are mainly due to enhanced basal motion and are a result of a changing spatial pattern of basal shear stress induced by subglacial hydrology. The observed speed-up events are clearly associated with major reorganizations of the basal drainage system, indicating that the basal drainage system is highly dynamic throughout the melt season. This implies that a general increase in meltwater supply as a consequence of a warming climate is not expected to enhance mean basal motion and therefore increase ice flux towards the margins.

For the second major speed-up event, the observed surface uplift and the close relation between surface flow and water pressure in a moulin suggest that the rapid increase in basal motion is most probably due to the formation and growth of basal cavities resulting from the high water pressure. The water pressure within the moulin reaching flotation level, and the fast down-glacier propagation of the velocity peak $\left(1 \mathrm{~km} \mathrm{a}^{-1}\right)$ indicate that decoupling may also have occurred over larger areas of the glacier bed. However, there are indications, from the phase relationship between observed vertical and horizontal motion, and a lag between the velocity peak and the pressure peak, that, although the short-term variations in basal motion are caused by high basal water pressure, basal motion is related to basal water storage rather than directly to basal water pressure, as suggested for large tidewater glaciers.

The general long-term flow pattern of the tidewater glacier Hansbreen differs from that of land-based valley glaciers of similar size. Surface velocity generally increases towards the terminus, and high basal sliding rates in the ablation area persist throughout the year. On short timescales, the observed variations in flow are, in terms of magnitude, duration and triggering mechanisms, very similar to those observed in land-based glaciers, and suggest that the controlling processes are similar. In addition, the observations at Hansbreen indicate no fundamental difference in the subglacial drainage system and glacial hydrology compared with land-based glaciers, although most parts of the glacier bed are below sea level.

\section{ACKNOWLEDGEMENTS}

We would like to thank K. A. Echelmeyer, G. H. G. Gudmundsson and D. Rippin for reading the manuscript and helping to improve it. We further appreciate the valuable comments of R. Naruse and two anonymous reviewers. Special thanks go to P. Vieser, who was responsible for the GPS survey in summer 1999 and helped in the field. The support given by M. Mächler of the Seminar für Statistik, ETH, Zürich for the velocity calculations using smoothing splines is gratefully acknowledged. The Geophysical Institute of the Polish Academy of Science provided the infrastructure of the Polish polar station in Hornsund during the field investigation. The work was supported by ETH grant No. 0-20-400-97, Zürich, Switzerland, and KTG grant No. PO4E 014 21, Poland.

\section{REFERENGES}

Bindschadler, R. 1983. The importance of pressurized subglacial water in separation and sliding at the glacier bed. F. Glaciol., 29(101), 3-19.

Boulton, G. S. and R. C. A. Hindmarsh. 1987. Sediment deformation beneath glaciers: rheology and geological consequences. F. Geophys. Res., 92(B9), 9059-9082. 
Fahnestock, M. A. 1991. Hydrologic control of sliding velocity in two Alaskan glaciers: observation and theory. (Ph.D. thesis, California Institute of Technology, Pasadena, CA.)

Fischer, U.H., G. K. C. Clarke and H. Blatter. 1999. Evidence for temporally varying "sticky spots" at the base of Trapridge Glacier, Yukon Territory, Canada. F. Glaciol., 45(150), 352-360.

Fowler, A. C. 1987. Sliding with cavity formation. 7. Glaciol., 33(115), 255-267.

Gudmundsson, G. H. 2002. Observations of a reversal in vertical and horizontal strain-rate regime during a motion event on Unteraargletscher, Bernese Alps, Switzerland. 7. Glaciol., 48(163), 566-574.

Gudmundsson, G. H., A. Bassi, M. Vonmoos, A. Bauder, U. H. Fischer and M. Funk. 2000. High-resolution measurements of spatial and temporal variations in surface velocities of Unteraargletscher, Bernese Alps, Switzerland. Ann. Glaciol., 31, 63-68.

Harrison, W. D., C. F. Raymond and P. MacKeith. 1986. Short period motion events on Variegated Glacier as observed by automatic photography and seismic methods. Ann. Glaciol., 8, 82-89.

Hooke, R. LeB., P. Calla, P. Holmlund, M. Nilsson and A. Stroeven. 1989. A 3 year record of seasonal variations in surface velocity, Storglaciären, Sweden. 7. Glaciol., 35(120), 235-247.

Humphrey, N., C. Raymond and W. Harrison. 1986. Discharges of turbid water during mini-surges of Variegated Glacier, Alaska, U.S.A. f. Glaciol., 32(111), 195-207.

Iken, A. and R. A. Bindschadler. 1986. Combined measurements of subglacial water pressure and surface velocity of Findelengletscher, Switzerland: conclusions about drainage system and sliding mechanism. f. Glaciol., 32(110), 101-119.

Iken, A. and M. Truffer. 1997. The relationship between subglacial water pressure and velocity of Findelengletscher, Switzerland, during its advance and retreat. f. Glaciol., 43(144), 328-338.

Iken, A., H. Röthlisberger, A. Flotron and W. Haeberli. 1983. The uplift of Unteraargletscher at the beginning of the melt season - a consequence of water storage at the bed? F. Glaciol., 29(101), 28-47.

Iverson, N. R., B. Hanson, R. L. Hooke and P. Jansson. 1995. Flow mechanisms of glaciers on soft beds. Science, 267(5194), 80-81.

Jania, J. 1988. Dynamiczne procesy glacjalne na poludniowym Spitsbergenie ( $w$ świetle badań fotointerpretacyjnych i fotogrametrycznych [Dynamic glacial processes in south Spitsbergen (in the light of photointerpretation and photogrammetric research)]. Katowice, Uniwersytet Slaski. (Prace Naukowe Uniwersytetu Sląskiego w Katowicach 955.) [In Polish with English summary]

Jania, J. and L. Kolondra. 1982. Field investigations performed during the glaciological Spitsbergen expedition in the summer of 1982: interim report. Sosnowiec, Poland, Uniwersytetu Slaskiego. Instytut Geografii.

Jansson, P. 1995. Water pressure and basal sliding on Storglaciären, northern Sweden. 7. Glaciol., 41(138), 232-240.

Jansson, P. and R. LeB. Hooke. 1989. Short-term variations in strain and surface tilt on Storglaciären, Kebnekaise, northern Sweden. F. Glaciol., 35(120), 201-208.

Kamb, B. and H. Engelhardt. 1987. Waves of accelerated motion in a glacier approaching surge: the mini-surges of Variegated Glacier, Alaska, U.S.A. F. Glaciol., 33(113), 27-46.

Kamb, B., H. Engelhardt, M. A. Fahnestock, N. Humphrey, M. Meier and D. Stone. 1994. Mechanical and hydrologic basis for the rapid motion of a large tidewater glacier. 2. Interpretation. 7. Geophys. Res., 99(B8), $15,231-15,244$
Lliboutry, L. 1968. General theory of subglacial cavitation and sliding of temperate glaciers. F. Glaciol., 7 (49), 21-58.

Lliboutry, L. 1979. Local friction laws for glaciers: a critical review and new openings. F. Glaciol., 23(89), 67-95.

Mair, D., P. Nienow, I. Willis and M. Sharp. 2001. Spatial patterns of glacier motion during a high-velocity event: Haut Glacier d'Arolla, Switzerland. F. Glaciol., 47(156), 9-20.

Meier, M. F. and A. Post. 1987. Fast tidewater glaciers. F. Geophys. Res., 92(B9), 9051-9058.

Meier, M. and 9 others. 1994. Mechanical and hydrologic basis for the rapid motion of a large tidewater glacier. 1. Observations. f. Geophys. Res., 99(B8), 15,219-15,229.

Meinck, M. 1998. Untersuchungen zum Fliessverhalten von Gletschern. (Diplomarbeit, Hochschule für Technik und Wirtschaft, Dresden.)

Naruse, R., H. Fukami and M. Aniya. 1992. Short-term variations in flow velocity of Glaciar Soler, Patagonia, Chile. 7. Glaciol., 38(128), 152-156.

Ohmura, A. 2001. Physical basis for the temperature-based melt-index method. 7. Appl. Meteorol., 40(4), 753-761.

O'Neel, S., K. A. Echelmeyer and R. J. Motyka. 2001. Short-term flow dynamics of a retreating tidewater glacier: LeConte Glacier, Alaska, U.S.A. 7. Glaciol., 47(159), 567-578.

Paterson, W. S. B. 1994. The physics of glaciers. Third edition. Oxford, etc., Elsevier.

Pillewizer, W. 1939. Die kartographischen und gletscherkundlichen Ergebnisse der Deutschen Spitzbergenexpedition 1938. Petermanns Geogr. Mitt., 238, 36-38. (Ergänzungsband.)

Raymond, C. F. and S. Malone. 1986. Propagating strain anomalies during mini-surges of Variegated Glacier, Alaska, U.S.A. f. Glaciol., 32(111), 178-191.

Raymond, C. F., R. J. Benedict, W. D. Harrison, K. A. Echelmeyer and M. Sturm. 1995. Hydrological discharges and motion of Fels and Black Rapids Glaciers, Alaska, U.S.A.: implications for the structure of their drainage systems. F. Glaciol., 41(138), 290-304.

Röthlisberger, H. 1972. Water pressure in intra- and subglacial channels. 7. Glaciol., 11(62), 177-203.

Seifert, B., M. Brockmann, J. Engel and T. Gasser. 1994. Fast algorithms for nonparametric curve estimation. 7. Comput. Graph. Statistics, 3, 192-213.

Truffer, M., K. A. Echelmeyer and W. D. Harrison. 2001. Implications of till deformation on glacier dynamics. F. Glaciol., 47(156), 123-134.

Van der Veen, C. J. 1996. Tidewater calving. 7. Glaciol., 42(141), 375-385.

Vieli, A., M. Funk and H. Blatter. 2000. Tidewater glaciers: frontal flow acceleration and basal sliding. Ann. Glaciol., 31, 217-221.

Vieli, A., J. Jania and L. Kolondra. 2002. The retreat of a tidewater glacier: observations and model calculations on Hansbreen, Spitsbergen. 7. Glaciol., 48(163), 592-600.

Vieser, P. 2000. GPS-Kampagne Spitzbergen 1999. (Diplomarbeit, Basel. Fachhochschule beider Basel

Voigt, U. 1979. Zur Blockbewegung der Gletscher. Vol. Reihe III. Berlin, Nationalkomitee für Geodätische und Geophysikalische der Akademie der Wissenschaften der Deutschen Demokratischen Republik. (Technical Report 443.)

Wadham, J. L., R. Hodgkins, R. J. Cooper and M. Tranter. 2001. Evidence for seasonal subglacial outburst events at a polythermal glacier, Finsterwalderbreen, Svalbard. Hydrol. Processes, 15, 2259-2280.

Willis, I. C. 1995. Intra-annual variations in glacier motion: a review. Prog. Phys. Geogr., 19(1), 61-106.

MS received 23 May 2002 and accepted in revised form 7 February 2004 